\title{
インドネシアにおける水力発電所建設工事の コンサルタント業務に参画して
}

\author{
右 近裕 之*
}

\section{1. プロジェクト概要}

コタパンジャン水力発電プロジェクトは, インドネシ ア共和国中部スマトラ, リアウ州の州都パカンバルの西 $85 \mathrm{~km}$ に位置しており, 中部スマトラ地域の電力安定供 給に寄与するとともにパカンバル地域の工業発展や西ス マトラ州との連携に寄与するのみならず道路整備による 地域開発や観光資源の開発振興等, 地域開発の中核とな るプロジェクトとして位置付けられている。同プロジェ クトは, バリサン山脈に源を発するカンパールカナン川 に堤高 $58 \mathrm{~m}$ のコンクリート重力式ダムを築造すること により，有効貯水容量 10.4 億トンの貯水池を創出する。 この水をダム左岸直下に位置する発電所に 3 条の水圧鉄 管で導水し, 最大使用水量 $348 \mathrm{~m}^{3} / \mathrm{s}$, 有効落差 $38.1 \mathrm{~m}$ により, 最大 $114 \mathrm{MW}$ の発電を行うものである。発電 した電力は, ダム左岸高標高部に設けた開閉所まで導か れ，そこでパカンバル方面执よび西スマトラ方面に各々 $65 \mathrm{~km}, 85 \mathrm{~km}$ の新設の送電線を経て供給される。また, 貯水池の出現により既設の国道, 州道が水没することに
伴い, 各々 $40 \mathrm{~km}, 22 \mathrm{~km}$ の付替道路を新設した。表-1 にプロジェクト諸元を示す。

このプロジェクトは，1982～83 年に実施された JICA によるフィージビリティー調査を経て, OECF 案件と して $87 \sim 88$ 年に詳細設計を実施し，91 年に着工した。 主要な工事は, 国際入札 10 工区, インドネシア国内入 札 3 工区に分かれ，日本業者を含め， 7 力国 18 業者が 単独または JVで施工を行った。プロジェクトの工区区 分ならびに施工業者を表-2 に示す。

ダムの湛水は, 工事進渉と閉塞ゲートの降下が可能と なる河川流量を考慮して 97 年 3 月に開始し, 水車発電 機の有水試験に必要な基準水位には計画どおり 7 月に到 達し, その後, 水車発電機の試験を開始した。土木構造 物は, 当初契約より 1 カ月早く 97 年 10 月に施主である インドネシア電力公社 (PLN) への引渡しを終え, 発 電所は 98 年 11 月に営業運転を開始した。

環境面では，貯水池の創出により約 4900 戸の住民に 移転の必要性が生じた。このため, インドネシア政府な らびに州政府は連携して移転地の新設を行うとともに,

表-1 プロジェクト諸元

\begin{tabular}{|c|c|c|c|c|c|}
\hline 河川名 & & $\begin{array}{l}\text { カンパール川水系 } \\
\text { カンパールカナン川 }\end{array}$ & 発電所 & $\begin{array}{l}\text { 型式 } \\
\text { 建屋 }\end{array}$ & $\begin{array}{l}\text { 地上式 } \\
35.6 \mathrm{~m} \times 80.3 \mathrm{~m} \times 43.2 \mathrm{~m}(H)\end{array}$ \\
\hline \multirow[t]{2}{*}{ 発電規模 } & \multirow{2}{*}{$\begin{array}{l}\text { 最大出力 } \\
\text { 最大使用水量 } \\
\text { 有効落差 } \\
\text { 年間発生電力量 } \\
\end{array}$} & \multirow{2}{*}{$\begin{array}{l}114 \mathrm{MW}(38 \mathrm{MW} \times 3) \\
348 \mathrm{~m}^{3} / \mathrm{s} \\
38.1 \mathrm{~m} \\
583 \mathrm{GWh}\end{array}$} & 水車 & $\begin{array}{l}\text { 型式 } \\
\text { 出力 } \times \text { 台数 } \\
\text { 回転数 }\end{array}$ & $\begin{array}{l}\text { 立軸カプラン } \\
39400 \mathrm{~kW} \times 3 \text { 台 } \\
200 \mathrm{rpm}\end{array}$ \\
\hline & & & \multirow{2}{*}{ 発電機 } & & 3 相交流型 \\
\hline \multirow[t]{3}{*}{ 貯水池 } & \multirow{3}{*}{$\begin{array}{l}\text { 総容量 } \\
\text { 有効容量 } \\
\text { 常時満水位 } \\
\text { 低水位. } \\
\text { 利用水深 } \\
\text { 湛水面積 } \\
\text { 集水面皘 } \\
\text { 年間平均流量 }\end{array}$} & \multirow{3}{*}{$\begin{array}{l}1545 \times 10^{6} \mathrm{~m} \\
1040 \times 10^{6} \mathrm{~m}^{3} \\
\text { El. } 85.0 \mathrm{~m} \\
\text { El. } 73.5 \mathrm{~m} \\
11.5 \mathrm{~m} \\
124 \mathrm{~km}^{2} \\
3337 \mathrm{~km}^{2} \\
184 \mathrm{~m}^{3} / \mathrm{s}\end{array}$} & & $\begin{array}{l}\text { 容量 } \times \text { 台数 } \\
\text { 電压/周波数 }\end{array}$ & $\begin{array}{l}45000 \mathrm{kVA} \times 3 \text { 台 } \\
11 \mathrm{kV} / 50 \mathrm{~Hz}\end{array}$ \\
\hline & & & 開閉所 & $\begin{array}{l}\text { 種類 } \\
\text { 容量 } \\
\text { 電圧 }\end{array}$ & $\begin{array}{l}\text { 屋外 } 3 \text { 相油入風冷式 } \\
10 \mathrm{MVA} \times 1 \text { 台 } \\
150 \mathrm{kV} / 20 \mathrm{kV}\end{array}$ \\
\hline & & & 送電線 & $\begin{array}{l}\text { 電压 } \\
\text { 延長 }\end{array}$ & $\begin{array}{l}150 \mathrm{kV} / 2 \text { 回線 } \\
64.4 \mathrm{~km} \text { (パカンバル) } \\
84.7 \mathrm{~km} \text { (西スマトラ) }\end{array}$ \\
\hline ダム & $\begin{array}{l}\text { 型式 } \\
\text { 提高 } \times \text { 堤頂長 } \\
\text { 堤体皘 }\end{array}$ & $\begin{array}{l}\text { コンクリート重力式 } \\
58.0 \mathrm{~m} \times 257.5 \mathrm{~m} \\
301300 \mathrm{~m}^{3}\end{array}$ & $\begin{array}{l}\text { 変電所 } \\
3 \text { 箇所 }\end{array}$ & $\begin{array}{l}\text { 種類 } \\
\text { 容量 } \\
\text { 電圧 }\end{array}$ & $\begin{array}{l}\text { 屋外 } 3 \text { 相油入風冷式 } \\
50-10 \mathrm{MVA} \\
150 \mathrm{kV} / 20 \mathrm{kV}\end{array}$ \\
\hline 洪水吐 & $\begin{array}{l}\text { 設計洪水流量 } \\
\text { ローラーゲート }\end{array}$ & $\begin{array}{l}8000 \mathrm{~m}^{3} / \mathrm{s} \\
18 \mathrm{~m}(H) \times 11 \mathrm{~m}(W) \times 5 \text { 門 }\end{array}$ & 付替道路 & & $\begin{array}{l}42.1 \mathrm{~km} \\
22.0 \mathrm{~km}\end{array}$ \\
\hline 水圧鉄管 & 管長 $\times$ 内径 $\times$ 条数 & $86.9 \mathrm{~m} \times 5.0 \mathrm{~m} \times 3$ 条 & & 橋りょう & 2 橋（293 m, $288 \mathrm{~m} ）$ \\
\hline
\end{tabular}


表-2 工区区分と請負業者一覧

\begin{tabular}{|c|c|c|c|}
\hline 工区 & 工事名 & 業者名 & 国名 \\
\hline I & 土木建築工事 & Hazama-Brantas J. O. & $\begin{array}{l}\text { 日本, インドネ } \\
\text { シア }\end{array}$ \\
\hline II & ゲート / 鉄管 & Sumitomo Corp. & 日本 \\
\hline III - A & 水車工事 & Kvaerner Boving Ltd. & 英国 \\
\hline III - B & 発電機工事 & Elin/Pt. Austrodwipa & オーストリア \\
\hline III - $\mathrm{C} 1$ & 開閉所機器 & Siemens & ドイッ \\
\hline III - $\mathrm{C} 2$ & 変電所機器 & Hyundai Corp. & 韓国 \\
\hline IV & 送電線機器 & $\begin{array}{l}\text { Nichimen-Taiyo Sinar J. } \\
\text { O. }\end{array}$ & $\begin{array}{l}\text { 日本, インドネ } \\
\text { シア }\end{array}$ \\
\hline V & $\begin{array}{l}\text { 洪水予測・下 } \\
\text { 流警報 }\end{array}$ & $\begin{array}{l}\text { PT. Gistec-Greenspan- } \\
\text { Elpro J. O. }\end{array}$ & $\begin{array}{l}\text { オーストラリア, } \\
\text { インドネシア }\end{array}$ \\
\hline $\mathrm{VI}-\mathrm{A}$ & 国道付替工事 & PT. Citra-Agra J. O. & インドネシア \\
\hline VI-B & 州道付替工事 & PT. Beringin Mas Jaya & インドネシア \\
\hline 5 & 送電線工事 & PT. Elmec Citra Tecnica & インドネシア \\
\hline 6 & 変電所工事 & PT. Idee Murni Pratama & インドネシア \\
\hline 7 & 送電線工事 & PT. Wika-PP J. O. & インドネシア \\
\hline
\end{tabular}

ゴム園，パームヤシ園や田畑等の生活再建方策を実施し， 1996 年初めまでに移転は完了した。また, 野生動物の 生態調查の結果を受け, 野生の象 41 頭を捕獲し保護区 へ移動した。

また，貯水池末端には 11〜12 世紀頃に建造された歴 史的にも重要な文化財であるムアラタクス仏教史跡があ る。この史跡保存のため, 本プロジェクトの常時満水位 を計画段階で史跡の敷地より低く抑えるとともに周辺道 路の整備を行うなど文化財の保存，保護に留意した。

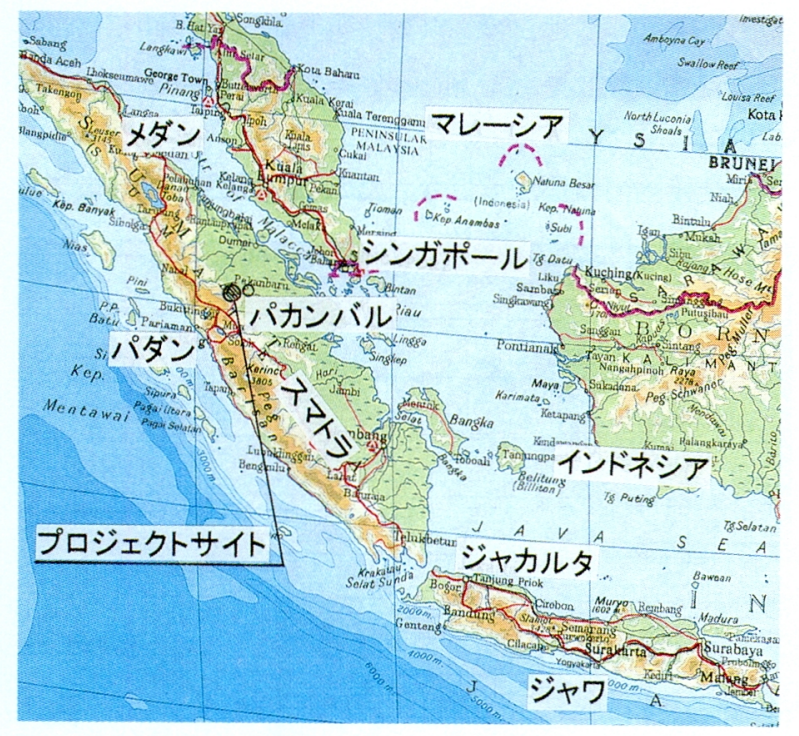

図-1 プロジェクト位置図

\section{2. コンサルタントの業務と位置付け}

\section{（1）業 務}

本プロジェクトでは, 東電設計が PLN とエンジニア サービス（工事管理・契約業務補助）契約を締結し，イ ンドネシアのコンサルタント 2 社と共同で業務を実施し
た。工事管理業務を開始する前段では, PLN が行う各 工区の業者選定業務, 入札審査, 契約業務の補助をジャ カルタで行い，工事管理業務はダムサイト近傍に設置さ れたPLNのベースキャンプ内にオフィスと宿舎が用意 され, ここにエンジニアが駐在し, 工事の品質, 出来形, 工程，予算，安全管理を行うとともに湛水前検査，竣工 検査，PLN 技術者への技術移転を行った。

業者選定の過程として本プロジェクトの第 I 工区（土 木建築工事）を例にあげると，当該工区には日本，イン ドネシアを含め 12 力国から，9共同企業体扔よび 1 単 独業者が入札に応じた。入札審査は，2段階に分けて実 施し, 第 1 次審查（一般審查）は, 入札図書の完成度, 入札者の資格審查，キイデートに従う工事工程等 7 項目 に対する審查結果と入札価格から，3者を選定した。そ の後第 2 次審査（詳細審査）では, 先に選定された 3 者 に対し，施工計画および手順，使用プラント・機器，工 事工程，組織，従事者の経験と資格，資金計画，下請会 社等 11 項目に対する審查結果と入札価格をむとに最低 価格を提示した企業体を選定した。

(2) エンジニアの位置付け

工事管理業務においてコンサルタントの位置付けは, 日本におけるむのより高く，施主との契約関係にあると いっても，あくまで施主ならびに請負業者の両者間にあっ てフェアな判断が求められる。したがって両者に対し, 公平かつ中立な立場を保つよう留意した。特に本プロジェ クトの場合，土木建築工事ならびに水圧鉄管・ゲート工 事の請負業者が日本であることから, 配慮が必要であっ た。また，請負業者からのクレームに対しは，あくまで 屯契約書類（仕様書，設計図，指示書等）に基づき公平 に，第三者から見られても当然だと考えられる判断を下 すよう配慮した。

\section{3. 設計, 検查基準等の現状}

プロジェクトに適用する設計基準等については，プロ ジェクトごとに, 施主とコンサルタント間で, 詳細設計 の段階で設計に使用する基準について協議を行い，定め ている。本プロジェクトの場合, 基本的には日本の設計 基準を適用した。しかし，現場の施主側のエンジニアか らアメリカ開拓局（USBR）やアメリカ陸軍工兵隊 （US Corps of Engineers）基準等を使った場合の説明 を求められることもあり，日本の基準類を瓶吞みにして 適用するのではなく，成立の経緯や適用範囲を理解する とともに他国の基準類についての知識も必要であると感 じた。

また，日本に扔ける河川法・電気事業法等に基づくダ ムコンクリート打設前の基礎岩盤検查や湛水開始前の検 查等はすべてエンジニアの判断に任されており，施主の 立会い検查前にエンジニアによる検查を実施し，その結 果に基づき，施主が確認する程度であった。 
湛水開始にあたっての許認可としては, 貯水池の所在 する州知事に対し, 施主が申請し, 許可を得るというシ ステムとなっていた。湛水計画や洪水の処理方法, 湛水 期間中の諸計測值の評価等についてもサイトの施主側工 ンジニアには逐次報告していたが, それ以外への報告は 義務付けられていないようであった。

\section{4. 工事管理について}

\section{(1) 工程管理}

工程管理については，プロジェクトの最終目的である 「工期内の確実な営業運転開始」のため, 各工区・業者 間の調整は必要不可欠なものである。国際入札の施工業 者は, 技術, 実績, 資金的には日本国内の業者と何ら遜 色はないが, 日本国内で行われるような業者間だけでの 調整は一部でしか行われず，ほとんどの問題はエンジニ アを仲介しないと解決しないものであった。そのため, 各工区に対し, 関連する他工区との工程調整が必要な部 分工事を対象にキイデートを設定し，これを基本に各工 区ならびに工区間調整，工程管理を行った。具体的には, 各工区ごとに現場進捗を週単位, 月単位で管理するだけ でなく, 関連工区のスケジュールをチェックする目的で, 現場に乗り込んでいない業者も含めて, 3 力月間隔で全 体調整連絡会議を開催し, 全体工程, 業者間の取り合い 等の調整を施主の出席のもと, エンジニア主導で行った。 同時に細部については関連する業者間で調整を行い，エ ンジニアもこれに参加し問題点を先送りすることのない よう留意した。

キイデートに関しては，関連工区が最も多い第 I工区 (土木建築工事) では，12 個のキイデートを設定した。 しかし，これらの中には工程上クリティカルとなるが季 節と河川流量に非常に影響を受けやすい「仮排水路によ る河川転流」と「ダム湛水開始」は含めなかった。転流

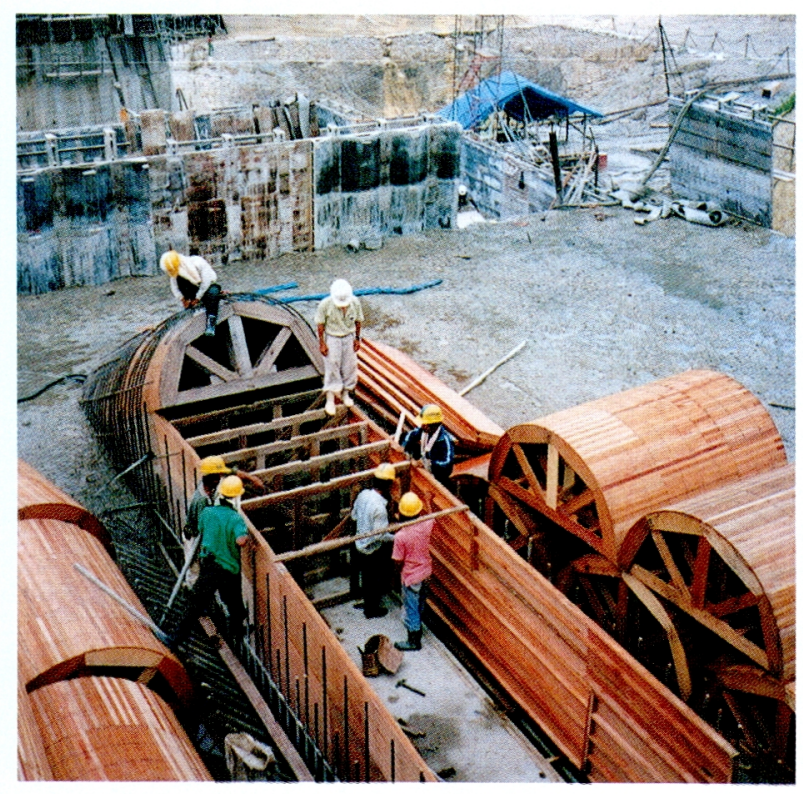

写真-1 ダム監査廊の木製型枠
時期に関しては請負業者の全面的な責任により決定され ることとし，また湛水開始は土木建築工事だけでなく関 連する工事（ゲート・鉄管，水車，発電機，付替国道等） の状況を勘案し，エンジニアが指示することとしていた。

プロジェクトサイトのように熱帯多雨地域では 4 月か ら 9 月までが乾季, 10 月から 3 月までが雨季と明瞭に 分かれており, 夕゙ム建設のための河川切替, 転流の時期 がプロジェクト全体の工程に大きく影響する。つまり河 川流量の大きい雨季に転流を行うことは，仮締切の構築 に多大な危険性と出費を伴う恐れがあることから，実施 することは難しい。したがって, 請負業者は乾季の末ま でに転流できない場合，次の乾季を待たざるを得ない状 況となり, 雨季の期間分工事が遅延し, 他工区とのキイ デートに遅れをきたすこととなり, その後の工事工程, 運転開始に多大な影響を及ぼすこととなる。本プロジェ クトでは, 資金貸与の合意の遅れにより着工が約半年遅 れたため, 仮排水路工事に関し数種の設計変更を行い, 当初計画どおりの雨季直前の転流を確保した経緯がある。

一方，現地業者は，国際入札で国道・州道の付替工事 に，国内入札で送電線・変電所工事に参入したが，技術 的にはさしたる問題はなかった。一部の業者では資金が 不足し，前受金をそのまま他の工事に転用し，当該工事 への着工が遅れたり, 本社からの送金が途絶え, 労賃, 燃料等の手当てができずに工事が中断したこともあった が, 送電線組立・架線工事以外は本プロジェクトのクリ ティカルパスでなかったので，全体工程に大きな影響を 及ぼさなかった。しかし，第５工区（送電線組立・架線 工事）では，業者に対し，鉄塔の基礎工事段階から投入 作業員数が少なく, 工事進渉が非常に遅いことを通知し 続けたにもかかわらず改善の兆しが見られなく, プロジェ クト全体への影響が危惧されたため，施主は当該業者と

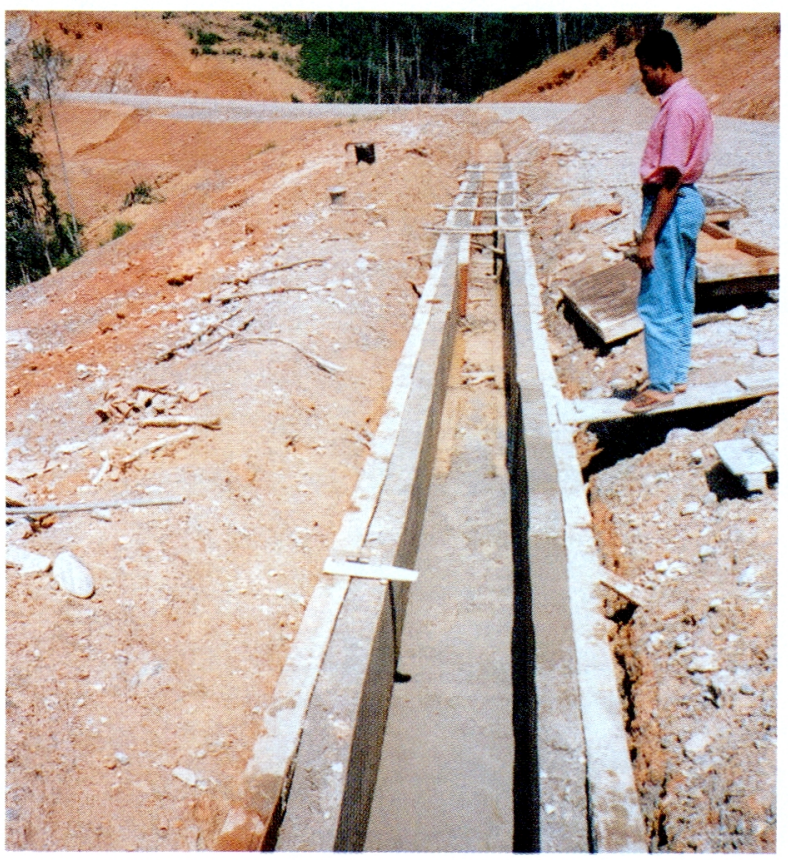

写真-2 現場打ちU 字側溝 
の契約を途中で終わらせ, 残工事に対して新たに業者を 選定し直し, 無事電気機器の試験に間に合わせた経緯が ある。

\section{（2）資 機 材}

資材面では，インドネシア国産セメントを使用する初 めての発電専用大規模コンクリートダムということでダ ムセメントについては品質面のみならず安定供給の面で む工事着工前に工場検査を実施するなど注目していたが 特段問題は生じなかった。しかし，メーカー側で出荷を 押さえ，值上がりを待つ向きがみられたこともあった。 他の土木建築関連資材では, 日本では普通に使われる U 字溝, 同蓋, グレーチング, コルゲートパイプ, フトン 籠等プレキャストの製品が少ないため, 現場製作が主体 となった。

また, 水車, 発電機, ゲート, 鉄塔, 鉄構等の主要機 材の本体や付属品は, 現地や業者の母国だけでなく, 世 界の至るところから調達され, 製作されている。発電機 の主要部分は受注メーカーの母国オーストリア製である が, それ以外は現地, オーストラリア, 韓国等から調達 されている。開閉所の鉄構部材はスペイン製であったり, 送電線鉄塔の部材はインドと現地製，架空導体はクウェー 卜製であったりする。当事者の業者む大変であるが，通 関書類に施主やエンジニアの承認を要するため，膨大な 書類が必要となってくる。インドネシアの通関手続の手 順が工事途中で変更となり，予定どおり円滑に輸入でき なかった例も多々あった。また，現地搬入前に仮組立を 行わず現地で初めて組立てるというケースでは, 部品の 品質, サイズ等が仕様に合わず苦労していた業者むあっ た。

東南アジアでは盗難が多いと言われるが，考えていた より少なかった。盗む方が悪いというより，盗まれるよ うな物を人前に置いておく方が悪いと考えるようになる くらいである。例えば，現場の資機材では，有刺鉄線を めぐらせた高さ $2 \mathrm{~m}$ のフェンスに囲まれ，24 時間ガー
ドマンの監視下にある場所から，貯水池の巡視用に用意 したモータボートの船外機（150馬力，ヤマ八製）が盗 難にあった。また，小さいものではダム監査廊に設置し た排水孔の水圧計はもとより鋼管やエルボまで盗難にあっ た。3 箇所ある監査廊の出入口には鋼製扉がありエンジ ニアと請負業者だけしか鍵を持っていないにもかかわら ず，錠を壊さずに盗難にあった。ベースキャンプ内では, 金品や洗濯物が盗まれたことがあった。しかし，鉄塔組 立のために鉄塔部材を，国道脇に 1 力月屯放置してあっ たにもかかわらず，盗まれたものはなかったことを併せ て記す。

5.おわりに

現地でのエンジニアリング業務を遂行する上で，人件 費抑制や地域事情に明るいことから，エンジニアのみな らず，インスペクター（工事監理補助），製図工，タイ ピスト，運転手等業務上必要な人のほか，宿舎にはコッ クやメイド等まで多数のローカルスタッフを雇用する必 要がある。赴任した時期が工事の終盤であったこともあ り，よい人材のみが残っていたと思う。しかし，日本人 スタッフの行動を良く見ており，仕事に対し真摰な態度 で向かっている人には，彼らも応じてくれる。しかし， 一度，ルーズにしてしまうと建て直しがきかない。人件 費の高い日本人が, 自ら行動で示さなければ, 動いてく れないし，ついてきてくれないというのが実感である。 また，日本を含む外国の業者は，コスト低減に向けて現 地の労働力のみならず技術力を最大限に利用しているし， 利用できるように ISO 等の資格を取得させる等努力し ている。コンサルタントについては, 一緒に働いたオー ストラリア人のエンジニアにみられたように指定された 役務の専門家であるのみならず，他の設計，積算，工事 管理等の業務全般に関して，基本的技術や経験を有して いることに驚きを覚えるとともに今後の日本人コンサル タントのあるべき姿であると痛感した。

図書案内

$\mathrm{JCl} 1999$

\section{コンクリート工学年次論文報告集 Vol. 21}

B 5 判・ 438 ページ (No. 1), 1428 ページ (No. 2), 1602 ページ (No. 3) 定価 24150 円 (税込), 会員特価 15750 円（税込）／送料 1000 円

-申込先：(社) 日本コンクリート工学協会・管理課「書籍販売係」

テ102-0083 東京都千代田区麹町 1-7 相互半蔵門ビル 12 階/電話（03）3263-1573

〈申込方法〉 書籍名・送付先を明記のうえ，前金（現金書留）にてお申込み下さい。 